\title{
PREVALENCE OF CARDIOGRAPHIC FINDINGS IN \\ PRE-PARTICIPATION ASSESSMENTS OF A \\ PROFESSIONAL SOCCER CLUB
}

\author{
PREVALÊNCIA DOS ACHADOS CARDIOGRÁFICOS NAS AVALIAÇÕES DE PRÉ-PARTICIPAÇÃO DE UM CLUBE \\ DE FUTEBOL PROFISSIONAL
PREVALENCIA DE LOS HALLAZGOS CARDIOGRÁFICOS EN LAS EVALUACIONES PRE PARTICIPACIÓNDE UN CLUB DE FÚTBOL PROFESIONAL

Fabrício Luz Cardoso'
(Clinical Academic)

Marcos Vinícius Muriano da Silva (Orthopedist and Sports Physician) José Antonio Galbiatti ${ }^{1}$

(Orthopedist)

1. Faculdade de Medicina de Marília (FAMEMA), Marília, SP, Brazil.

\section{Correspondence:}

Fabrício Luz Cardoso. Avenida Monte Carmelo, 800, Fragata, Marília, SP, Brazil. 17519-030. fabricioramalhense@gmail.com

\begin{abstract}
Objectives: To analyze the results of pre-participation tests applied to soccer players from a professional club, aiming to compare the cardiographic findings with the literature and encourage the development of new strategies for the prevention of sudden death. Methods: We used a sample group of 110 male soccer players. Stages of the study: 1) collection of data from the pre-participation tests (cardiac history, electrocardiogram, exercise test and echocardiogram) using a form covering three years (2015 to 2017); 2) tabulation of data using Word and Excel Office 2010 software; 3) comparison with the literature. Results: Of the athletes studied, 55.5\% had sinus bradycardia and 14.5\% had ventricular repolarization abnormalities, $33.3 \%$ showed evidence of minimal tricuspid regurgitation, and $45.7 \%$ had physiological pulmonary regurgitation. The echocardiogram presented some interesting data when compared to the adult non-athlete population. In the ergometric test, $53.6 \%$ of the athletes reached the maximum stage and $46.4 \%$ discontinued the test due to physical fatigue. Regarding arrhythmias, in $21.8 \%$ of the patients we observed rare isolated ventricular extrasystoles and in $8.2 \%$ rare isolated supraventricular extrasystoles. Conclusion: The findings corroborate data from the literature on exercise and sports cardiology, since they mainly represent physiological adaptations of the athlete's heart. The sports physician is responsible for monitoring athletes to prevent sudden death. Level of Evidence Il; Retrospective study.
\end{abstract}

Keywords: Soccer; Sports medicine; Cardiology; Sudden cardiac death.

\section{RESUMO}

Objetivos: Analisar os resultados dos exames de pré-participação dos atletas de um clube de futebol profissional, visando confrontar os achados cardiográficos com a literatura e incentivar o desenvolvimento de novas estratégias para a prevenção da morte súbita. Método: Utilizamos uma amostra com 110 atletas, jogadores de futebol do sexo masculino. Etapas do estudo: 1) coleta de dados dos exames de pré-participação (anamnese cardiológica, eletrocardiograma, teste ergométrico e ecocardiograma), através de formulário, em um período de três anos (2015 a 2017); 2) tabulação dos dados utilizando os softwares Word e Excel Office 2010; 3) confrontação com a literatura. Resultados: Dos atletas estudados, 55,5\% apresentaram bradicardia sinusal e 14,5\% alteração na repolarização ventricular, 33,3\% evidenciaram refluxo tricúspide mínimo e 45,7\% apresentaram refluxo pulmonar fisiológico. O ecocardiograma apresentou alguns dados interessantes quando comparados à população adulta não atleta. No teste ergométrico, atingiram o estágio máximo 53,6\% dos atletas e 46,4\% interromperam o teste por cansaço físico. Em relação às arritmias, em 21,8\% observaram-se extrassístoles ventriculares isoladas e raras e em 8,2\% extrassístoles supraventriculares isoladas e raras. Conclusões: Os achados reforçam os dados da literatura de cardiologia do exercício e esporte, pois, representam, em sua maioria, adaptações fisiológicas do coração do atleta. Cabe ao médico do esporte o acompanhamento clínico dos atletas, visando prevenção da morte súbita. Nível de Evidência ll; Estudo retrospectivo.

Descritores: Futebol; Medicina esportiva; Cardiologia; Morte súbita cardíaca.

\section{RESUMEN}

Objetivos: Analizar los resultados de los exámenes de pre participación de los atletas de un club de fútbol profesional, con el fin de confrontar los hallazgos cardiográficos con la literatura e incentivar el desarrollo de nuevas estrategias para la prevención de la muerte súbita. Método: Utilizamos una muestra de 110 atletas, jugadores de fútbol del sexo masculino. Etapas del estudio: 1) colecta de datos de estos exámenes de pre participación (anamnesis cardíaca, electrocardiograma, test ergométrico y ecocardiograma), a través de formulario, en un período de tres años (2015 a 2017); 2) tabulación de los datos utilizando los softwares Word y Excel Office 2010; 3) confrontación con la literatura. Resultados: De los atletas estudiados, 55,5\% presentaron bradicardia sinusal y 14,5\% alteración en la repolarización ventricular, 33,3\% evidenció reflujo tricúspide mínimo y 45,7\% presentaron reflujo pulmonar fisiológico. El 
ecocardiograma presentó algunos datos interesantes cuando comparados a la población adulta no atleta. En el test ergométrico, alcanzaron la etapa máxima 53,6\% de los atletas y 46,4\% interrumpió la prueba por cansancio físico. Con cuanto a las arritmias, en 21,8\% se observaron extrasístoles ventriculares aisladas y raras, y en 8,2\% extrasístoles supraventriculares aisladas y raras. Conclusión: Los hallazgos refuerzan los datos de la literatura de cardiología del ejercicio y deporte, pues representan en su mayoría, adaptaciones fisiológicas del corazón del atleta. Cabe al médico del deporte el acompañamiento clínico de los atletas buscando la prevención de la muerte súbita. Nivel de Evidencia Il; Estudio retrospectivo.

Descriptores: Fútbol; Medicina deportiva; Cardiología; Muerte súbita cardíaca.

\section{INTRODUCTION}

Football is the most popular sport in the world, practiced by 400 million people, 30 million of which in Brazil. ${ }^{1,2}$ Since it is an activity characterized by more dynamic (isotonic) periods and few isometric (static) periods, as well as an aerobic and anaerobic metabolism, football played in the field promotes physiological adaptations in the athlete's body throughout its practice. ${ }^{3}$

These changes are manifested in concentric cardiac hypertrophy, caused by periods of isometric and anaerobic exercise, as well as the development of eccentric cardiac hypertrophy due to periods of isotonic and aerobic exercise. As such, the heart of the football athlete increases in diameter in the atrial and/or ventricular cavities, as does the thickness of the heart wall. ${ }^{4-7}$

The association between unsuspected cardiovascular diseases and sudden cardiac death in athletes is no mere coincidence. The probability increases with the performance of competitive sports and the rates reach up to $90 \%$ of the occurrences of deaths during trainings or competitions. ${ }^{6,8}$

Pathophysiologically, the triggering mechanisms of sudden death are: immediate and significant reduction in cardiac output secondary to myocardial ischemia, onset of lethal arrhythmias and reduced cerebral blood flow resulting in loss of consciousness. ${ }^{9}$

After the death of a football player during the start of the Brazilian Championship of 2004, more studies related to the subject have been published in Brazil. In 2005, the Brazilian Society of Sports and Exercise Medicine (Sociedade Brasileira do Exercício e do Esporte, SBMEE) defined the concept of sudden cardiac death as "death that occurs unexpectedly, whether instantaneously or not, or death that occurs within a period of 6 to 24 hours after the practice of physical activity and sport by athletes", and the society suggested a pre-participation assessment. This proposal is in alignment with international protocols, such as European and American ones..$^{8-11}$

The guideline recommends a clinical pre-participation assessment based on an anamnesis, evaluating the subject's medical history, family history of heart disease and/or premature sudden deaths, social history and life habits, in addition to laboratory exams: Hemoglobin electrophoresis, VDRL/FTA-Abs, Chagas disease blood test, resting ECG, exercise stress test, cardiopulmonary exercise test or ergo-spirometry and echocardiogram. ${ }^{9}$

The objective of this study was to analyze the results of the pre-participation examinations of professional football athletes in order to confront the most prevalent findings with the literature and encourage the development of new strategies for the prevention of sudden death.

\section{MATERIALS AND METHODS}

This study is retrospective in nature and is characterized as a quantitative research based on the gathering and treatment of epidemiological data on prevalence and confrontation with the current literature. It focused on analyzing the results of the reports of the cardiologic exams of the pre-participation assessments of football athletes from a professional football club, falling within the field of cardiology applied to exercise and sports medicine, with the objective of identifying prevalent alterations. We obtained the approval of the Ethics and Research Committee (CEP) under report no. 2,097,005 and the same committee exempted the requirement of signing the informed consent form.

The study was developed in three stages: the first stage was characterized by gathering the data that can be found in the charts and reports of the cardiologic pre-participation exams of the professional football club performed in a Heart Institute of the private health care network, within a period of three years (2015 to 2017). All athletes were men between 17 and 37 years of age. The inclusion criteria were: (1) Play or have played for the professional football club in the period from 2015 to 2017, and (2) have participated in the pre-participation assessment before official competitions in the described period. The identification was done with the use of initials to preserve the identity of the athlete.

We collected the data with a collection form (Appendix 1A and $1 B)$, which had a total of four pages. The first page of the form was used to gather the data from the athletes' medical records. The second page was used to collect data related to the echocardiogram. The third page referred to the exercise stress test and the fourth and last page interpreted the results of the electrocardiogram.

In the second stage, we tabulated the data gathered in the forms using the Office Word and Excel 2010 software in order to separate the information of interest found, i.e. the more prevalent findings of the exams, and, in principle, to use simple statistics to obtain their percentage in relation to the total number of exams without changes in each class (electrocardiogram, echocardiogram or exercise stress test).

In the third and last stage, the data found in our study was confronted with the most recent literature so as to see if our findings corroborate or contradict the findings of other studies.

\section{RESULTS}

We evaluated the pre-participation examinations of 110 athletes from a professional football club, with all athletes being of the male sex. The mean age was 23.2 years (standard deviation $=4.72$ ), with the youngest athlete being 17 years old and the oldest 37.

The athletes could be subdivided into four main categories regarding the positions they played: 11 goalkeepers (10\%), 32 defenders (29.1\%), 36 midfielders (32.7\%) and 29 forwards (26.4\%). We were not able to identify the positions of two athletes (1.8\%).

\section{Cardiologic anamnesis and physical examination}

A specific anamnesis was performed in the 110 athletes prior to the pre-participation examinations, as is usual for the performance of cardiological examinations. In this anamnesis, 107 athletes (97.3\%) had an asymptomatic cardiovascular condition, one athlete $(0.9 \%)$ reported a history of atypical chest pain, but denied having pal pitations or syncope, one athlete 
(0.9\%) stated having a history of cardiac murmur, and one athlete (0.9\%) had a prior history of atrioventricular block. All athletes denied: smoking, alcoholism, a personal history of systemic hypertension and dyslipidemia. Only two athletes (1.8\%) reported having family members with diabetes mellitus, a father and grandfather, respectively. All footballers denied having a family history of congestive heart failure and stroke, and four athletes (3.6\%) reported a family history of acute myocardial infarction: two of a grandmother of 48 and 50 years, respectively, and one uncle of 33 years and a father of 58 years with fulminating heart attacks.

In the physical examination, the lowest and highest resting heart rate values measured were 43 and 91 bpm, respectively, with the mean being $58.4 \mathrm{bpm}$ (standard deviation $=10$ ). The mean systolic blood pressure was $122 \mathrm{mmHg}$ (standard deviation = 7.83) and the mean diastolic blood pressure was $77.7 \mathrm{mmHg}$ (standard deviation = 4.60), with 57 athletes (51.8\%) having a blood pressure of $120 \times 80 \mathrm{mmHg}$. The other data from the physical examination (referring to sinus bradycardia and BP above normality) are shown in Table 1.

\section{Electrocardiogram}

The athletes were submitted to an electrocardiographic evaluation, the results of which are summarized in Table 2. One athlete described a history of prior atrioventricular block during the anamnesis, but nothing was detected in the electrocardiogram.

\section{Echocardiogram}

The echocardiogram was performed in only 81 athletes, the other athletes did not take it because in 2015 the Medical Department only recommended these examinations for athletes with observed changes in the electrocardiogram and/or a positive family history for cardiovascular events. For these athletes, we found a mean age of 23.0 years (standard deviation $=4.98$ ), with the youngest athlete being 17 years old and the oldest 37.

The mean size of the posterior wall of the left ventricle in 81 athletes was $0.88 \mathrm{~cm}$ (standard deviation $=0.12$ ), the mean diastolic diameter was $5.1 \mathrm{~cm}$ (standard deviation =0.35), the mean systolic diameter was $3.3 \mathrm{~cm}$ (standard deviation $=0.17$ ), the mean ejection fraction (monoplane) was 0.64 (standard deviation $=0.05$ ) and the mean thickness/volume ratio was 0.35 (standard deviation $=0.06$ ). Other data of interest can be seen in Table 3 .

\section{Exercise stress test}

the stress test was performed with the Ellestad protocol as reference. ${ }^{12}$ Table 4 shows the results found.

Table 1. Findings of the physical examination.

\begin{tabular}{c|c|c}
\hline Condition & $\begin{array}{c}\text { No. of athletes } \\
(\mathbf{N}=110)\end{array}$ & $\begin{array}{c}\text { Percentage of the } \\
\text { sample }\end{array}$ \\
\hline Sinus bradycardia & 61 & $55.5 \%$ \\
\hline $\begin{array}{c}\text { Blood pressure above normal values } \\
\text { (suggesting the hypothesis of a systolic } \\
\text { hypertension diagnosis) }\end{array}$ & 1 & $0.9 \%$ \\
\hline
\end{tabular}

Table 2. Electrocardiogram findings.

\begin{tabular}{c|c|c}
\hline Condition & $\begin{array}{c}\text { No. of } \\
\text { athletes } \\
(\mathbf{N}=110)\end{array}$ & $\begin{array}{c}\text { Percentage of } \\
\text { the sample }\end{array}$ \\
\hline Change in ventricular repolarization & 16 & $14.5 \%$ \\
\hline Conduction disturbance in the right branch & 5 & $4.5 \%$ \\
\hline First-degree atrioventricular block & 3 & $2.7 \%$ \\
\hline Early repolarization pattern & 2 & $1.8 \%$ \\
\hline Isolated ventricular extrasystoles & 1 & $0.9 \%$ \\
\hline Isolated supraventricular extrasystoles & 1 & $0.9 \%$ \\
\hline Anterosuperior left hemi-block & 1 & $0.9 \%$ \\
\hline
\end{tabular}

Table 3. Echocardiogram findings.

\begin{tabular}{c|c|c}
\hline Condition & $\begin{array}{c}\text { No. of athletes } \\
(\mathbf{N}=\mathbf{8 1})\end{array}$ & $\begin{array}{c}\text { Percentage of } \\
\text { the sample }\end{array}$ \\
\hline Mild concentric hypertrophy & 1 & $1.2 \%$ \\
\hline $\begin{array}{c}\text { Mitral valve with minimum } \\
\text { superior systolic motion }\end{array}$ & 9 & $11.1 \%$ \\
\hline $\begin{array}{c}\text { Turbulent systolic flow in the proximal third } \\
\text { of the left atrium in the mitral Doppler, } \\
\text { characterizing mild mitral insufficiency }\end{array}$ & 2 & $2.5 \%$ \\
\hline $\begin{array}{c}\text { Minimum tricuspid regurgitation } \\
\text { (physiological) in the tricuspid Doppler. }\end{array}$ & 27 & $33.3 \%$ \\
\hline $\begin{array}{c}\text { Pulmonary regurgitation (physiological) } \\
\text { in the pulmonary Doppler }\end{array}$ & 37 & $45.7 \%$ \\
\hline
\end{tabular}

Table 4. Exercise stress test findings

\begin{tabular}{c|c|c}
\hline \multicolumn{3}{c}{ Ellestad protocol } \\
\hline Condition & $\begin{array}{c}\text { No. of athletes } \\
(\mathbf{N = 1 1 0 )}\end{array}$ & $\begin{array}{c}\text { Percentage of } \\
\text { the sample }\end{array}$ \\
\hline $\begin{array}{c}\text { reached stage 7 of the protocol (maximum } \\
\text { stage). concluding the test without chest pain }\end{array}$ & 59 & $53.6 \%$ \\
\hline Interrupted the test in stage 6 without chest pain & 41 & $37.3 \%$ \\
\hline Interrupted the test in stage 5 without chest pain & 10 & $9.1 \%$ \\
\hline
\end{tabular}

Interrupted the test in stage 5 without chest pain

\begin{tabular}{c|c|c}
\hline \multicolumn{3}{c}{ Arrhythmias } \\
\hline Condition & $\begin{array}{c}\text { No. of athletes } \\
(\mathbf{N = 1 1 0 )}\end{array}$ & $\begin{array}{c}\text { Percentage of } \\
\text { the sample }\end{array}$ \\
\hline isolated and rare ventricular extrasystoles & 24 & $21.8 \%$ \\
\hline Isolated and rare supraventricular extrasystoles & 9 & $8.2 \%$ \\
\hline $\begin{array}{c}\text { Isolated and rare ventricular and } \\
\text { supraventricular extrasystoles }\end{array}$ & 1 & $0.9 \%$ \\
\hline Absence of arrhythmias & 76 & $69.1 \%$ \\
\hline
\end{tabular}

\section{DISCUSSION}

Studies in the field of exercise and sports medicine have shown that several factors can contribute to morpho-functional cardiac changes, such as sex, age, ethnicity and the sports modality practiced. The great challenge is that these changes that characterize the so-called "Athlete's Heart" can mimic the changes found in some heart diseases, including hypertrophic cardiomyopathy, which is a risk factor for the occurrence of sudden death in athletes. ${ }^{10,13}$

In a survey on the internet of global journalistic data related to heart-related sudden deaths in football players during games or trainings, spanning a period of 111 years (1906 - January 2017), we found 65 records of sudden death in a total of 119 records of death, which represents $54.6 \%$ of the cases. Of these, $56.9 \%$ were due to acute myocardial infarction (AMI), 38.5\% due to cardiorespiratory arrest (CA) and $4.6 \%$ due to complications arising from hypertrophic cardiomyopathy. In total, eight cases occurred in Brazil, four of which due to AMI and four due to CA.

Sudden cardiac death in athletes occurs in a wide age range, going from younger athletes to athletes with little more than 35 years of age. Below 35 years of age, the most frequent causes are congenital heart disease, of which hypertrophic cardiomyopathy and the anomalous origin of the left coronary artery are the most prevalent. Over 35 years of age, coronary artery disease (CAD) is the most common cause. $6,9-11,13-17$ In this study, the athletes'age ranged from 17 to 37 years, coinciding with the cited age range.

The report of atypical chest pain confirmed as benign after a thorough anamnesis of an athlete leads us to agree with Rich, ${ }^{18}$ who stated that atypical chest pains in athletes are often the result of a discomfort in the chest wall or of costochondritis. We also agree with Giese et. al. ${ }^{19}$ who claim that in some cases the chest pain in athletes may be a manifestation of stress-induced asthma.

The history of cardiac murmur reported by one 18-year-old athlete corroborates Wassersten and Teixeira ${ }^{20}$, who stated that innocent murmurs are frequent in young athletes, lean individuals, and especially in children. Most of the time these murmurs are mesosystolic, of short 
duration, and may increase in intensity in the supine position and decrease while sitting and/or performing maneuvers that limit the venous return.

We support what was described in the study of Siebra et. al., ${ }_{1}^{17}$ who state that the presence of chronic diseases like diabetes is a risk factor for the development of atherosclerotic disease of the coronary artery (the main cause of sudden death in individuals over 35 years), and the prevention of the development of these diseases, which has a considerable genetic component, is therefore paramount in athletes. Regarding the investigation of the family history of heart disease, we cite the studies of Maron et. al. ${ }^{8}$ and Otsuka et. al., ${ }^{21}$ who respectively demonstrated that hypertrophic cardiomyopathy (HCM) is a common hereditary cardiac pathology with a prevalence of $0.2 \%$ in the general population (1:500 individuals) and that more than half of individuals with HCM have a family history of the disease or sudden death, with the remaining cases being attributed to spontaneous mutations.

We agree with what Chaitman and Fromer ${ }^{22}$ and Maron ${ }^{23}$ described in their studies regarding athlete's heart syndrome, which includes clinical, electrocardiographic and echocardiographic alterations, such as sinus bradycardia and myocardial hypertrophy. These changes are secondary to prolonged and regular practice of physical exercise and reveal the adaptation of the cardiovascular system to metabolic and hemodynamic changes that are induced by effort and are meant to increase the efficiency of the cardiovascular function. In most cases, the values remain within the limits of normality. Regarding this claim, our findings corroborate those of the authors, since in a considerable part of the athletes, the hearts had cavity volumes at the upper limit of normality, which is compatible with adaptive changes of the athlete's heart.

We agree with the studies by Corrado et. al. ${ }^{24}$, Maron and Pelliccia ${ }^{25}$ and Topol et. al. ${ }^{26}$ who demonstrated that during the practice of sports, an athlete's cardiac output is superior to the non-athlete individual. However, when in rest, these values are similar in both groups. Since changes occur in the autonomous nervous system resulting from the adaptations of the athlete's heart, it is common to find sinus bradycardia (defined as a rate lower than $60 \mathrm{bpm}$ that may reach $25 \mathrm{bpm}$ ) in athletes, as was found in over half of the athletes in our study. The studies also describe atrioventricular conduction delays caused by increased parasympathetic tone and decreased sympathetic tone, which justifies our finding of conduction disturbances in the right branch in five athletes.

Our findings of changes in the ventricular repolarization and early repolarization pattern are in accordance with those reported by Topol et. al., ${ }^{26}$ who associate most repolarization abnormalities with the practice of isotonic exercises (such as football), suggesting that these alterations shouldn't be considered as electrocardiographic changes. In addition, the authors argue that many alterations in the electrocardiogram of the athlete, such as the changes in the ST segment and sinus arrhythmia, may be present in young, non-athlete and healthy individual and that the occurrence of a physiological remodeling is not necessary for these traces to arise in these individuals.

The presence of first-degree atrioventricular block and Wenckebach periods in our study is in alignment with what was described by Corrado et. al., ${ }^{24}$ who demonstrated the presence of first-degree atrioventricular block in approximately $35 \%$ of the athletes and Wenckeback-type atrioventricular block in approximately $10 \%$ of the athletes. The presence of hemiblocks is also common in athletes.

In the echocardiogram, a mild concentric left ventricular hypertrophy was found in one athlete, which according to Ghorayeb et. al. ${ }^{15}$ is a common adaptive and purely physiological process of an athlete's heart.

The findings of a minimum superior systolic motion of the mitral valve, turbulent systolic flow in the proximal third of the left atrium characterizing mild mitral insufficiency, minimum tricuspid regurgitation and physiological pulmonary regurgitation, are all alterations resulting from small blood regurgitations that occur through the heart valves, and these are often present not only in athletes, but also in the adult, non-athlete population. According to Ghorayeb et. al. ${ }^{15}$, when these regurgitations are physiological in nature, they do not preclude the practice of sports, and the absence of signs and symptoms in the affected athletes would indicate this sanctioning of sports practice.

The mean size of the posterior wall of the left ventricle was $0.88 \mathrm{~cm}$, slightly above the mean of 0.87 for the Brazilian asymptomatic adult male population described in the study by Angelo et. al. ${ }^{27}$ The mean diastolic diameter and the mean systolic diameter found in our study were 5.1 and $3.3 \mathrm{~cm}$, respectively. These values are higher than the means found in the study by Angelo et. al. ${ }^{27}$ for Brazilian, asymptomatic, non-athlete men, which was $4.99 \mathrm{~cm}$ for the diastolic diameter and $2.99 \mathrm{~cm}$ for the systolic diameter.

The assessment of the left ventricular systolic function can be done through the ejection fraction. The mean ejection fraction (monoplane) in our study was 0.64 , or $64 \%$, close to the value of 0.6 , or $60 \%$, found by Cabanelas et al. ${ }^{28}$ in 27 football players with a mean age of 24.7 years (near the mean of our study of 23.2 years) in the echocardiographic pre-season examination.

Based on the studies by Ferreira Filho ${ }^{29}$ and Armstrong et al., ${ }^{30}$ we believe that the greater the thickness/volume ratio (values greater than or equal to 0.45 ), the greater is the left ventricular wall thickness in relation to the systolic volume (concentric hypertrophy - increase of the sarcomeres in parallel), and the lower the value of this ratio (values less than or equal to 0.45 ), the higher the systolic volume in relation to the thickness of the left ventricular wall (eccentric hypertrophy - increase of sarcomeres in series). The mean value of the thickness/volume ratio of 0.35 found in our study, therefore, is suggestive of eccentric hypertrophy.

The presence of arrhythmias (isolated and rare ventricular and/ or supraventricular extrasystoles) is in agreement with the findings described by Ghorayeb et. al., ${ }^{15}$ who associated them to an increase in the sympathetic autonomic modulation imposed by graded exercise, which therefore are non-pathological changes when it comes to athletes.

The exercise stress test is important in the evaluation of physical capacity and we agree with Ghorayeb et. al. ${ }^{15}$ that a weak capacity for exercise indicates a poor prognosis, which was not shown in our study since all the athletes completed more than half of the evaluation stages.

\section{CONCLUSIONS}

The findings corroborate the data from the exercise and sports cardiology literature, since they mostly represent physiological adaptations of the athlete's heart. It is up to the sports physician to perform the clinical follow-up of athletes through pre-participation examinations associated with an anamnesis and physical examination. The results of these examinations allow the physician to carefully assess the condition of the athlete and give guidance regarding appropriate behaviors that seek to prevent sudden death based on a clinical follow-up of the athlete.

\section{ACKNOWLEDGMENT}

To Marilia athletic club (MAC), for allowing the study to be carried out.

To the Supervisor of Soccer of the Marilia Athletic Club, Jose Luiz Tedeschini, by all support in the stage of data collection.

To Prof. João Saes Braga Ph.D, for the technical support in obtaining the exams and printing the reports.

To the medical doctors of the Sport Club Corinthians Paulista, Dr. Ivan Grava and Dr. Júlio Stancati Filho, for kindly reviewing the research and contributing suggestions.

To the Physical Educator and Football Technician, José Ivan Doreto Campanari Júnior, for the aid in the identification of the positions in which the athletes played.

All authors declare no potential conflict of interest related to this article 
AUTHORS' CONTRIBUTIONS: Each author made significant individual contributions to this manuscript. FLC (0000-0002-9507-4170)*contributed in the acquisition, analysis and interpretation of data for the work; writing of the article; final approval of the version of the manuscript to be published; agreed to be held accountable for all the aspects of the work, by ensuring that any issues related to the integrity or accuracy of any part of the work are duly investigated and resolved. MVMS (0000-0001-6986-661X)* collaborated in the conception and drafting of the research project and design of the work; critical review of the intellectual content of the work; final approval of the version of the manuscript to be published. JAG (0000-0003-2330-3816)* assisted in the creation of the design of the work; critical review of the intellectual content of the work; final approval of the version of the manuscript to be published. *ORCID (Open Researcher and Contributor ID).

\section{REFERÊNCIAS}

1. FédérationInternationale de Football Association. (2007). FIFA Big Count 2006: 270 million people active in football. 2007 [acesso em 25 mar 2018]. Disponível em: www.fifa.com/aboutfifa/organisation/media/ news/ newsid=529882/index.html.

2. Stolen T, Chamari K, Castagna C, Wisloff U. Physiology of soccer: an update. Sports Med. 2005;35(6):501-36

3. Barros Neto TL. Hipertrofia ventricular secundária ao exercício físico. RevSocCardiol Est São Paulo. 1994;4:376-81.

4. McArdle WD, Katch FI, Katch VL. Transferência de energia no exercício. In: McArdle WD, Katch Fl, Katch $V L$, editores. Fisiologia do exercício: energia, nutrição e desempenho humano. Rio de Janeiro: Guanabara Koogan; 2003. p.161-74.

5. Perez AB, Rodrigo AB, Fernández JRB, Alcaine RL, Fernándes EL, Marqueta PN, et al. Guías de Práctica Clínica de laSociedadEspañola de Cardiología sobre laactividad física em elcardiópata. RevEspCardiol. 2000;53(5):648-726

6. Suarez-Mier MP, Aguilera B. Causes of sudden death during sports activities in Spain [in Spanish] RevEspCardiol. 2002;55(4):347-58.

7. Tebexreni AS, Silva MAP, Carvalho ACC. Cardiopatias congênitas: atividades físicas e esporte. RevSocCardiol Estado de São Paulo.2005;15:169-83.

8. Maron BJ, Thompson PD, Ackerman MJ,Balady G, Berger S, Cohen D, et al. Recommendations and considerations related to preparticipation screening for cardiovascular abnormalities in competitive athletes: 2007 update: a scientific statement from the American Heart Association Council on Nutrition, Physical Activity, and Metabolism: endorsed by the American College of Cardiology Foundation. Circulation. 2007;115(12):1643-55

9. Oliveira MAB, Leitão MB, Nóbrega ACL, Hernandez AJ, Baptista C, Araújo CGS, et al. Morte súbita no exercício e no esporte. RevBrasMed Esporte. 2005;11(Supl. 1):S1-8.

10. Corrado D, Pelliccia A, Bjornstad HH, Thiene G. Cardiovascular pre-participation screening of young competitive athletes for prevention of sudden death: proposal for a common European protocol; reply. Eur Heart J. 2005;26(5):1804-5

11. Pelliccia A, Di Paolo FM, Corrado D, Buccolieri C, Quattrini FM, Pisicchio C, et al.Evidence for efficacy of the Italian national pre-participation screening programme for identification of hypertrophic cardiomyopathy in competitive athletes. Eur Heart J. 2006;27(18):2196-200.

12. Ellestad MH. Protocolo do teste de esforço. In: Prova de Esforço. $2^{\mathrm{a}}$ ed. Rio de Janeiro: Cultura Médica; 1984.p. 105-26.

13. Riding NR, Salah O, Sharma S, Carre F, O'Hanlon R, George KP, et al. Do big athletes have big hearts? Impact of extreme anthropometry upon cardiac hypertrophy in professional male athletes. Br J Sports Med. 2012;46(Suppl 1):i90-7.

14. Garcia JH, Costa MPF. Morte súbita em atletas: protocolos e rotinas adotados por clubes de futebo profissional em São Paulo. RevBrasMed Esporte. 2011;17(3):161-5.

15. Ghorayeb N, Lejderman B, Ramos EGSS, Castro I, Zimerman LI, Pimentel M. Diretriz em Cardiologia do Esporte e do Exercício da Sociedade Brasileira de Cardiologia e da Sociedade Brasileira de Medicina do Esporte. ArqBrasCardiol. 2013;100(1Suppl.2):1-41.

16. Pigozzi F, Spataro A, Fagnani F, Maffulli N. Preparticipation screening for the detection of cardiovascula abnormalities that may cause sudden death in competitive athletes.Br J Sports Med. 2003;37(1):4-5.

17. Siebra FBA, Filho GSF. Morte súbita em atletas: fatores predisponentes e Preventivos. RevBrasClinMed. 2008;6:184-90.

18. Rich BSE. Triagem para morte súbita. In: McKeag DB. Clínicas médicas da América do Norte: Medicina desportiva. Rio de Janeiro: Interlivros; 1994. p.271-93.

19. Giese EA, O'Connor FG, Brennan FH, Depenbrocket PJ, Oriscello RG. The athletic preparticipation evaluation: cardiovascular assessment. AmFamPhysician. 2007;75(7):1008-14.

20. Wassersten M, Teixeira JAC. Morte súbita: avaliação pré-esportiva das principais causas cardíacas não traumáticas em adolescentes e jovens adultos. Adolesc Saúde. 2008;5(3):33-43.

21. Otsuka H, Arimura T, Abe T, Kawai H, Aizawa Y, Kubo T, et al. Prevalence and distribution of sarcomeric gene mutations in Japanese patients with familial hypertrophic cardiomyopathy. Circ J. 2012;76(2):453-61

22. Chaitman BR, Fromer M. Should ECG be required in young athletes? Lancet. 2008;371(9623):1489-90.

23. Maron BJ. Distinguishing hypertrophic cardiomyopathy from athlete's heart physiological remodelling: clinical significance, diagnostic strategies and implications for preparticipation screening. Br J Sports Med. 2009;43:649-656.

24. Corrado D, Biffi A, Basso C,Pelliccia A, Thiene G.12-Lead ECG in the athlete: physiological versus pathological abnormalities. Br J Sports Med. 2009;43(9):669-76.

25. Maron BJ, Pelliccia A. The heart of trained athletes: cardiac remodeling and the risks of sports, including sudden death. Circulation. 2006;114(15):1633- 44

26. Topol E. Textbook of Cardiovascular Medicine. 3rd ed. Philadelphia, Pa: Lippincott Williams and Wilkins; 2007

27. Ângelo LCS, Vieira MLC, Lamego S, Morelato RL. Medidas ecocardiográficas de referência em amostra da população brasileira adulta sem doença cardio- vascular. Rev Bras Ecocardiogr. 2008;21(2):12-7.

28. Cabanelas N, Freitas S, Gonçalves L. Evolução das características morfofuncionais do coração do atleta durante uma época desportiva. Revista Portuguesa de Cardiologia. 2013;32(4):291-6.

29. Ferreira Filho PRP. Padrões de hipertrofia e geometría do ventrículo esquerdo pela ecocardiografiatranstorácica. RevBrasEcocardiogr Imagem Cardiovasc. 2012;25(2):103-15

30. Armstrong W, Ryan T, Feigenbaum H. Feigenbaum'sechocardiography. 7th ed. Philadelphia, Pa:Wolters Kluwer/Lippincott Williams \& Wilkins; 2010. p. 139-80. 


\begin{tabular}{|l|l|}
\hline \multicolumn{2}{|c|}{ Data collection form - Cardiological anamnesis } \\
\hline Study: “Prevalence of cardiographical findings in pre-participantion evalutions of a professional football club.” \\
\hline Name Initials & Habits \\
Age & Personal background \\
Weight & Family History \\
Height & Complementary exams \\
Position you play in & Physical exam \\
Year of Consultation & Diagnostic hypothesis \\
Main complaint and history & Conduct \\
Medications in Use & Comments \\
\hline
\end{tabular}

\section{Data collection form - Echocardiogram}

Study: "Prevalence of cardiographical findings in pre-participantion evalutions of a professional football club."

Diameters and Left Ventricular Systolic Function

Descriptions of the Left Ventricle

Segment Shrinkage

Evaluation of Left Ventricular Diastolic Function

Left Atrium and Mitral valve

Aortic valve

Aorta

Right atrium

Lower Cava vein

\author{
Right ventricle \\ Tricuspid valve \\ Pulmonary valve \\ Pericardium \\ Doppler Mitral \\ Aortic Doppler \\ Tricuspid Doppler \\ Pulmonary Doppler \\ Conclusions
}

Appendix 1B.

\begin{tabular}{|l|l|}
\hline \multicolumn{2}{|c|}{$\begin{array}{c}\text { Data collection form - Ergometric test } \\
\text { Study: “Prevalence of cardiographical findings in pre-participantion evalutions of a professional football club.” }\end{array}$} \\
\hline Test indication & Ellestad Protocol \\
Complaints & Stage \\
Medicines & Recovery \\
Risk factors & Electrocardiographic changes \\
Physical activity & Arrhythmias \\
Physical exam & Behavior of PA \\
Basal electrocardiogram & Comments \\
Predicted heart rate & Conclusions \\
\hline
\end{tabular}

Data collection form - Electrocardiogram

Study: "Prevalence of cardiographical findings in pre-participantion evalutions of a professional football club." 